substances used in his anti-tuberculous treatment, it must not be concluded that our researches are necessarily upon exactly the same lines. Koch has stated that his liquid is a "glycerine extract of pure cultivations of the tubercle bacillus," and without further details it is impossible to interpret the exact meaning of this expression, and it does not necessarily follow, however probable it may be, that our extract of glycerine-broth cultivations, or the substances isolated therefrom, would produce exactly similar results to those produced by Koch's fluid.

\section{CASE OF AINHUM.}

By H. J. McC. TODD, Staff-Surgeon, R.N. H.M.S. Hagicienne. (Communicated by the Director-General of the Medical. Department of the Navy.)

As cases of this disease are not frequently reported, a short account may interest some of the readers of the BRITISH Menicai. Journal.

King Twala, aged 30, Krooman, was placed on the sick list complaining of pain and swelling of both little toes, which presented the following appearances. The left toe was enlarged to twice its natural size, and was twisted on its axis so that the nail looked outwards, and was so loosely comnected to the foot that I feared he would lose the member if it struck against anything. He had no power of moving it in association with the other toes, and its sensation was very deficient. On a level with the web of the toe was a very tight constriction, which on the inner and plantar surface had ulcerated, but on the outer side was represented by a firm band of fibrous tissue; the right little toe was surrounded by a similar tight band, which, however, had not broken down. This man states that his left toe was first affected four years ago, and his right about one year sinc.e.

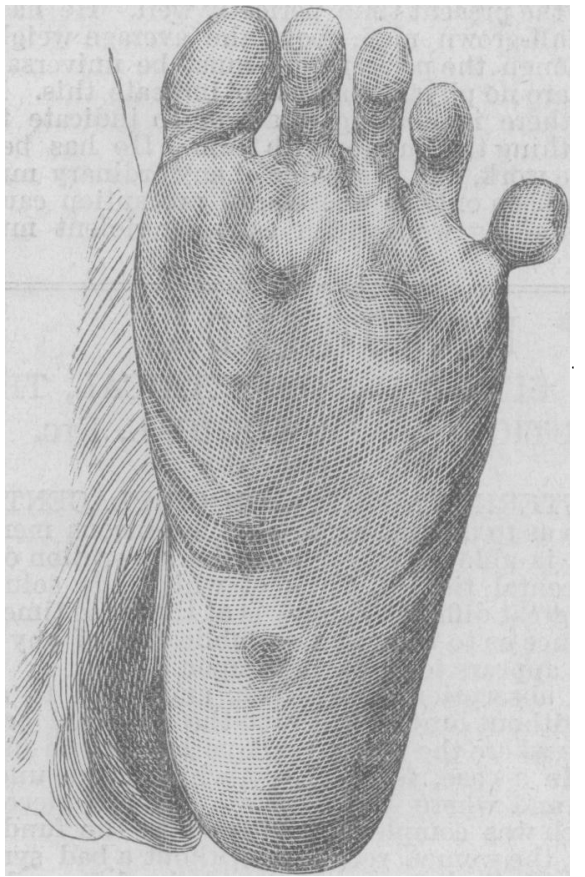

On inquiry into his family and previous history, I can find no cause for this disease, excepting the prevalence of this affection in that part of the West Coast from which he comes, and from his description the disease must be extremely com mon there, the popular remedy being to tie a piece of string over the seat of the constriction, and to tighten this from time to time until the toe drops off, this occupying about three months. This man is of very good physique, and, excepting his troublesome toes, is. in excellent health. As he wished to have the toe removed on account of the discomfort it caused and his inability to walk, I amputated it at the metatarso-phalangeal joint, previously injecting cocaine. The operation was painless.

On examining the excised portion, I found the constricting hand had reduced the structures below it to great thinness. There was a greatly increased development of adipose tissue in the enlarged portion, giving the sensation of fluid before removal.

\section{CASE OF CESOPHAGOTOMY.}

\section{By THOMAS H. MORSE, F.R.C.S.ENG.} Norwich.

THe operation of œsophagotomy is, I am surprised to find, a very rare one. I hope, therefore, the present case may prove of interest. Mr. Durham, in Holmes's System of Surgery, speaks of it as having been performed so long ago as 1738, and that since then as many as forty-five cases have been recorded. On two occasions it was performed at Guy's Hospital by $\mathbf{M r}$. Cock, for the removal of tooth plates.

The present case occurred on January 11th, 1890. The patient, a woman, aged 32, whilst bolting her dinner and at the same time attending to the impatient indicator of a telegraphic machine, suddenly felt that she had swallowed a foreign body, which gave her considerable pain. The pain, which was increased by pressure, was situated on the left side of the neck just below the cricoid cartilage. An œsophageal bougie when passed was suddenly arrested at a distance of $6 \frac{1}{2}$ inches from the teeth, and the passage of both liquid and solid food was obstructed.

With the able assistance of Dr. Hills, Mr. Warlters, and Mr. Cecil Muriel, an attempt was first made with a coincatcher, but this failing to remove it, the operation was at once proceeded with.

An incision three inches long was made in the left side, on the inner border of the sterno-mastoid muscle, terminating below at the level of the sterno-clavicular joint. After dividing the superficial fascia, the platysma, and the deep fascia with several superficial veins, the omo-hyoid muscle was seen crossing the upper angle of the wound, and, as it interfered with the deeper dissection, it was divided between two ligatures. The dissection was now chiefly carried out with the tips of the two forefingers. The jugular vein and common carotid artery were exposed for about two inclies. On the inner side of the wound was the thyroid gland, and deeper down the inferior thyroid artery, running horizontally into the gland was distinctly seen. Next the junction of the larynx and trachea, with

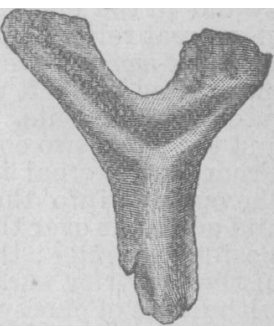

Bone of fowl-natural size. corresponding portions of the pharynx and cesophagus, and rumning upwards between these two tubes, was seen the recurrent laryngeal nerve. A hard substance could now be felt in the osopliagus, and this organ was next separated from the cervical vertebre and rotated on its long axis, for the purpose of making an opening into its posterior aspect, in order to avoid the recurrent laryngeal nerve. A small opening was made with scissors, and gradually dilated as the foreign body was removed with forceps. The œesophageal wound was not sutured. The skin was closed with silver wire, two drainage tubes being inserted. I need not enter into the details of the after-treatment, except to mention that although no food or drink was given by the mouth at all for three days, yet the pangs of hunger were entirely prevented by nutrient enemata in the form of suppositories. By degrees water, and afterwards milk, were swallowed, small quantities nceasionally coming through the wound, and causing the discharge to be offensive, but recovery was practically uninterrupted, and was complete in three weeks.

Should a similar case ever occur to me, I should feel much inclined to suture the oesophageal wound.

The foreign body was a portion of one of the rib bones of a fowl, and measured 1 inch in breadth and nearly $1 \frac{1}{2}$ iuch in length. 